\title{
Regulation of lumen fat digestion: enzymic aspects
}

\author{
BY ROBERT VERGER, MUSTAPHA AOUBALA, \\ FRÉDÉRIC CARRIÈRE, STÉPHANE RANSAC, \\ LILIANE DUPUIS, JOSIANE DE CARO,
} FRANCINE FERRATO, ISABELLE DOUCHET, RENÉ LAUGIER AND ALAIN DE CARO

UPR 9025, Laboratoire de Lipolyse Enzymatique, IFRC1 du CNRS 31 Chemin Joseph-Aiguier, 13402 Marseille Cedex 20, France

\section{Aspects enzymatiques de la digestion intraluminale des lipides}

\section{RÉSUMÉ}

Les triacylglycérols, qui constituent la majeure partie (90 à $95 \%$ ) de l'alimentation lipidique chez l'homme, subissent dans l'estomac une hydrolyse partielle en diacylglycérols et acides gras sous l'action d'une lipase préduodénale (lipase gastrique, linguale ou pharyngienne selon les espèces). Au niveau du duodénum l'émulsion formée de triacylglycérols, diacylglycérols et acides gras entre en contact avec les sécrétions pancréatiques et biliaires. Grâce à l'action principale de la lipase pancréatique et à celle de la lipase gastrique, les triacylglycérols et les diacylglycéroles sont entièrement convertis en monoacylglycérols et acides gras qui sont absorbés par les cellules de la bordure en brosse intestinale, sous forme de micelles mixtes avec les sels biliaires.

Les lipases préduodénales sont stables et actives en milieu acide. La purification et la caractérisation des résidus d'amino acides essentiels à l'activité enzymatique (sérine au site catalytique, et groupe sulfhydryle) ont été réalisées sur les lipases préduodénales. De nombreuses lipases préduodénales ont été clonées et une grande homologie dans les séquences a été observée.

Des anticorps monoclonaux anti-lipase gastrique humaine ont été utilisés d'une part comme marqueurs spécifiques des sites fonctionnels et d'autre part pour l'immunopurification de l'enzyme ainsi que pour la mise au point d'un dosage immunoenzymatique de type ELISA qui permet de discriminer entre la lipase pancréatique et la lipase gastrique présentes dans des prélèvements duodénaux.

La résolution de la structure tridimensionnelle de la lipase pancréatique humaine a révélé la présence d'une triade catalytique (Ser 152-Asp 176-His 263) semblable à celle observée chez les hydrolases à sérine ainsi que la présence de deux domaines structuraux. Plusieurs complexes de cette enzyme avec son cofacteur protéique, la colipase, ont été co-cristallisées avec un analogue de substrat, ainsi que des inhibiteurs de type phosphonate. Ces études nous ont permis de proposer qu'en présence d'une interface lipide-eau, l'enzyme subissait des changements conformationnels importants, conduisant à une forme 'ouverte' du complexe, c'est-à-dire active.

Until recently, the hydrolysis of dietary fats, of which about $95 \%$ are triacylglycerols (TAG; Rizek et al. 1974), was thought to begin in the intestinal lumen and to be catalysed entirely by pancreatic lipase (EC 3.1.1.3). The stomach was thought of as a 
transient storage organ whose role was limited to mixing and dispersing lipids with the other nutrients. Although many authors observed the occurrence of preduodenal lipolysis in human subjects and several other species, the gastric phase of lipolysis was assumed to be negligible and non-significant in comparison with the intestinal step. Gastric lipolysis was even attributed to pancreatic contamination after a duodeno-gastric reflux.

At the beginning of the century, Volhard (1901) stated that gastric lipase (EC 3.1.1.3) is the 'ferment' present in gastric juice and that it is responsible for fat hydrolysis. Finally, as early as 1917, the gastric origin of the lipase present in dog gastric juice was demonstrated by Hull \& Keaton (1917) in dogs with Pavlov stomachs under conditions precluding the possibility of any pancreatic contamination. These findings were neglected for many years until the physiological importance of preduodenal lipolysis was indirectly demonstrated in some cases of pancreatic lipase deficiency, such as cystic fibrosis and chronic pancreatitis, and in premature infants where the pancreatic enzyme and bile secretion levels are very low. In all these cases about $70 \%$ of the ingested dietary fat is absorbed (Ross \& Sammons, 1955; Roulet et al. 1980; Hamosh, 1984). In the case of the newborn, the maternal milk fat is hydrolysed under the action of both bile salt-dependent lipase present in human milk and gastric lipase whose secretion starts before birth (Hamosh, 1984). However, the exact physiological contribution of the preduodenal lipase to overall lipolysis has not yet been clearly established. Bernbäck et al. (1989) have shown that the fatty acids liberated during gastric hydrolysis of milk TAG facilitate the subsequent action of pancreatic lipase in the duodenal lumen. Moreover, an in vitro study has shown that TAG emulsions covered by phospholipids are not hydrolysed directly by human pancreatic lipase (HPL; Borgström, 1980). However, pre-incubation of an emulsion of soyabean oil stabilized by phospholipids (Intralipid ${ }^{\mathrm{TM}}$ ) with human gastric lipase (HGL) promotes the subsequent action of HPL (Gargouri et al. 1986); the effect on the activity of HPL is more marked when the pre-incubation period of the emulsion with HGL is increased. This finding suggests that the role of HGL is to hydrolyse part of the dietary TAG, thus facilitating the subsequent action of HPL. The fatty acids liberated during gastric hydrolysis modify the quality of the emulsion allowing easier access of HPL to TAG. This interpretation is strengthened by the fact that the presence of oleic acid with HPL induces the same effect as that observed after pre-incubation in the presence of HGL. The fact that HGL can hydrolyse the TAG emulsions covered by a phospholipid monolayer shows that this enzyme has higher 'penetration' properties than HPL. These important findings show that the HGL and HPL hydrolyse dietary TAG and act synergistically in the gastrointestinal tract.

In order to purify and characterize preduodenal lipases, screening assays were carried out along the upper digestive tract (from the tongue to the pylorus) of several mammals (de Nigris et al. 1988; Moreau et al. 1988b). In each species tested, the preduodenal lipase activity was associated mainly with a single tissue, which was located either in the lingual, the pharyngeal or the gastric area (Fig. 1). In contrast to pancreatic lipase, all these lipases were characterized by their high stability and high levels of enzymic activity under acidic $\mathrm{pH}$ conditions. To date, rat lingual (Hamosh et al. 1979; Field \& Scow, 1983; Roberts et al. 1984), HGL (Tiruppathi \& Balasubramanian, 1982), calf and lamb pharyngeal (Bernbäck et al. 1985; de Caro et al. 1995), rabbit gastric (RGL) (Moreau et al. 1988a) and dog gastric (DGL) (Carrière et al. 1991) lipases have been purified and biochemically characterized. 


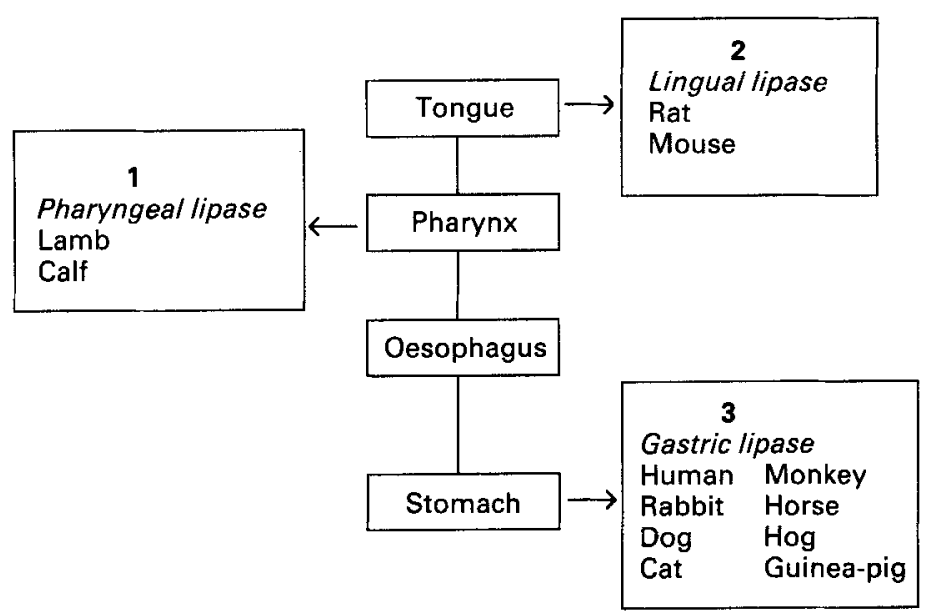

Fig. 1. Anatomical sites of preduodenal lipases in several mammals.

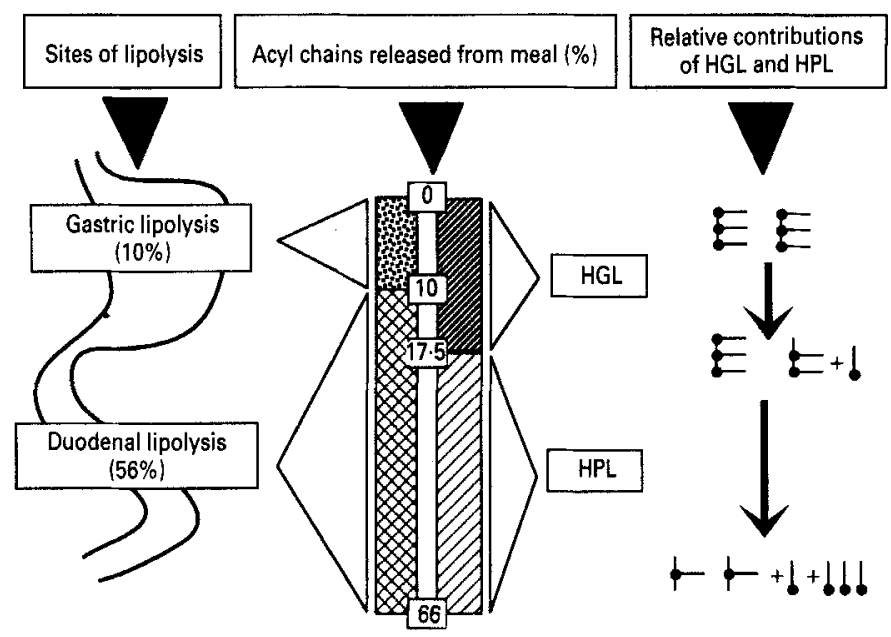

Fig. 2. Schematic representation of the relative contributions of human gastric lipase (HGL) and human pancreatic lipase (HPL) to the overall digestion of dietary triacylglycerols. (From Carrière et al. 1993.)

Recently, in our laboratory the investigations of Carrière et al. (1993), carried out on healthy volunteers without any pancreatic or gastric deficiency, allowed them to define the respective physiological contributions of preduodenal lipase and HPL in the overall hydrolysis of dietary TAG. The authors stated that, during the digestion of a liquid test meal, $66 \%$ of TAG hydrolysis was sufficient for complete absorption and HGL and HPL hydrolysed 18 and $48 \%$ of the meal TAG-acyl chains respectively. In other words, preduodenal lipase hydrolysed one acyl chain out of four which need to be hydrolysed for complete intestinal absorption of two TAG molecules (Fig. 2).

We have recently studied the secretion and the contribution of HGL in patients 
suffering from severe pancreatic deficiencies (Mossi et al. 1994). Six patients were included in this study (four men, two women; 41.5 (SD 6.3) years) and compared with sixteen healthy controls. All patients presented with an advanced stage of chronic pancreatitis; 10.8 (SD 7.8) years of clinical duration, all had calcifications, four steatorrhoea and five diabetes mellitus. HPL concentration in the duodenum was below $20 \%$ of the lower limit of normality. A standard meal (containing $11.5 \mathrm{~g}$ lipids, mainly as long-chain TAG) induced secretion of HGL which was comparable with that of the controls $(19.1$ (SD 3.2) v. 22.6 (SD 8.1) mg), while HPL accounted for only 8.9 (SD 2.1) v. 88.2 (SD 21.5 ) $\mathrm{mg}$ in controls. Since duodenal $\mathrm{pH}$ is more acidic (minimum $\mathrm{pH} 4.4 v .5 \cdot 7$ ) preduodenal lipase should have greater activity over a longer part of the small intestine. Thus, we concluded that there is no compensatory hypersecretion of HGL in a group of patients with severe pancreatic deficiencies (in terms of the amount of secretion). In this group of patients with virtually no HPL secretion, preservation of a normal HGL secretion becomes essential for lipolysis; two of the six patients did not develop significant steatorrhoea.

\section{BIOCHEMICAL CHARACTERIZATION}

The amino acid sequence derived from cDNA analysis showed that HGL consisted of a single polypeptide of 379 amino acids with a molecular mass of $43 \mathrm{kDa}$ (Bodmer et al. 1987). The primary sequences of four preduodenal lipases have been determined (Fig. 3): rat lingual lipase (Docherty et al. 1985), RGL and DGL (Bénicourt et al. 1993), and calf pharyngeal lipase (Timmermans et al. 1994). Recently, the primary sequence of lamb pharyngeal lipase was partially sequenced (de Caro et al. 1995). A high degree of sequence homology (up to $80 \%$ ) was found to exist between HGL and the other preduodenal lipases. These exocrine lipases also have a high homology with the intracellular human lysosomal acid lipase of liver (Fig. 3); its amino acid sequence was found to be $58 \%$ identical to that of HGL (Anderson \& Sando, 1991).

The calculated molecular mass of HGL polypeptide $(43 \mathrm{kDa})$ is lower than that of the native enzyme purified from gastric juice $(50 \mathrm{kDa})$, indicating that $\mathrm{HGL}$ is a glycoprotein containing about $15 \%$ carbohydrates. This was confirmed by the occurrence of three major SDS-PAGE bands with lower molecular masses, down to a band of $43 \mathrm{kDa}$, when HGL was incubated with endoglycosidase F (Moreau et al. 1992). Depending on the specificity of endoglycosidase F, its ability to remove all the carbohydrates linked to HGL suggests that the glycan moiety of HGL consists of asparagine-linked carbohydrates. From the primary sequence it was predicted that HGL possesses four potential glycosylation sites (Asn-X-Ser/Thr) conserved in the sequence of RGL and DGL (Asn 15, Asn 80, Asn 252 and Asn 308). Three of them were found to occupy equivalent positions in rat lingual lipase (Asn 15, Asn 80, Asn 252) and in lamb pharyngeal lipase (Asn 15, Asn 252 and Asn 308). The high level of glycosylation of preduodenal lipases confers on them a high degree of heterogeneity. Unlike the analysis on SDS-PAGE, isoelectrofocusing pattern of HGL, DGL and RGL showed multiple bands which were broader for RGL and HGL than for DGL. The observed isoelectric points ranged between 5.8 and 7.2 with RGL, between 6.8 and 7.8 with HGL (four isoforms) and between 6.3 and 6.5 with DGL (Moreau et al. 1992).

According to the amino acid sequence, three cysteine residues were detected per molecule of HGL (Cys 227, Cys 236 and Cys 244) and other gastric lipases, except for 


\begin{tabular}{|c|c|}
\hline & 50 \\
\hline HGL & LFGKLHPGSPEVTMNISQMITYWGYPNEEYEVVTEDGYILEVNRIPYGKK \\
\hline DGL & LFGKLHPTNPEVTMNI SQMITYWGYPAEEYEVVTEDGYILGIDRIPYGRK \\
\hline RGL & LFGKSAËTNPEVNMNI SQMI SYWGYPSEKYEVVTEDGY ILEVNRI PYGKK \\
\hline $\mathbf{R L} \mathbf{L}$ & LFGKLGPGNPEANMNI SQMITYWGYPCQEYEVVTEDGYILGVYRIPHGKN \\
\hline CPL & ELGK I - AKNPEASMNVSQMI SYWGYPSEMHKVITADGYILQVYRIPHGKN \\
\hline LPL & FLGKI-AENPEASMNVSQMISFWGYPSEMHKVITAD \\
\hline HLAL & SGGKLTAVDPETMMVSEI ISYWGFPSEEYLVETEDGYILCLNRI PHGRK \\
\hline
\end{tabular}

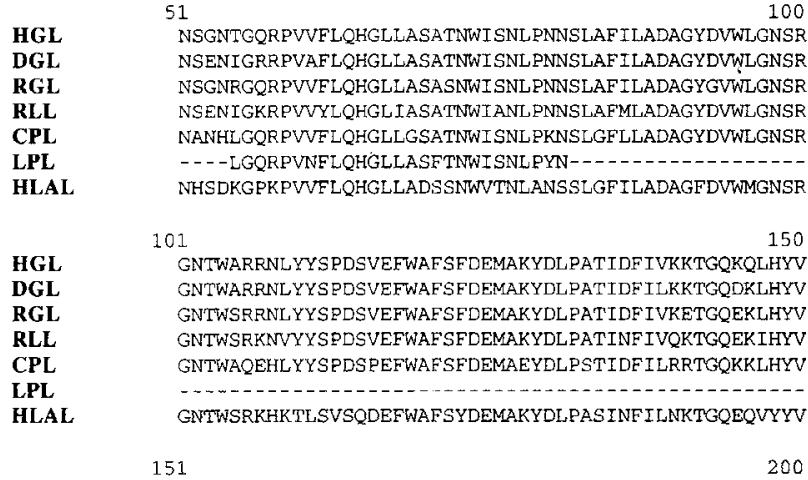

HGL GHSOGTTIGFIAFSTNPSLAKRIKTFYALAPVATVKYTKSLINKLRFVPO

DGL GHSQGTTIGFIAFSTNPKLAKRIKTFYALAPVATVKYTETLLNKLMLVPS

RGL GHSOGTTIGFIAESTNPKLAERIKTFYALA PVATVKYTKSLVNKLRFIPP

RLL GHSQGTTIGFIAFSTNPTLAKKIKTFYALAPVATVKYTQSPLKKISFIPT

CPL GHSQGTTIGFTAFSTSPTLAEKIKVFYALAPVATVKYTKSLFNKEALIPH

HLAL HLLSOGTIGFIAFSQI PELAKRIKMFFALGPVASVAFCTSPMAKLGRIPD

HLAL

$\begin{array}{ll}\text { HGL } & \text { SLFKFIFGDKIFY FHNFFDQFLATEVCSREMLNLLCSNALFIICGFDSKN } \\ \text { DGL } & \text { FLFKLIFGNKIFY PHHFFDQFLATEVCSRETVDLLCSNALFI ICGFDTMN }\end{array}$

RGL TMFKIIFGDKIFY PHNFFDQFLATQVCSRETLNVICSNALFIICGFDSAN

RLL FLFKLMFGKKMFLFHTYFDDFLGTEVCSREVLDLLCSNTLFIFCGFDKKN

CPL $\quad$ FLFKIIFGDKMFY PHTELEQFLGVEMCSRETLDVLCKNALFAITGVDNKN

LPL

HLAL HLIKDLFGDKEFLPQSAFLKWLGTHVCTHVILKELCGNLCFLLCGFNERN

2512300

DGL LNMSRLDVYLSHNPAGTSVQNVLHWSQAVKSGKFQAFDWGSPVQNMMHYH

RGL LNMSRLDVYVSHNFAGTSVQNMLHWTQAVKSGNFQAFNWGSPAQNVVHFN

LLR LNVSREVYLGHNFAGTSVQDFLHWAQLVRSGKFQAFNWGSPSONMLHYN

CPL FNMSRLDVYIAFNPAGTSVONTLHWRQAVKSGKFQAFDWGAPYQNLMHYH

LPL HLAL LNMSRVDVYTTHSPAGTSVQNMLHWSQAVKFQKFQAFDWGSSAKNYFHYN

HLAL

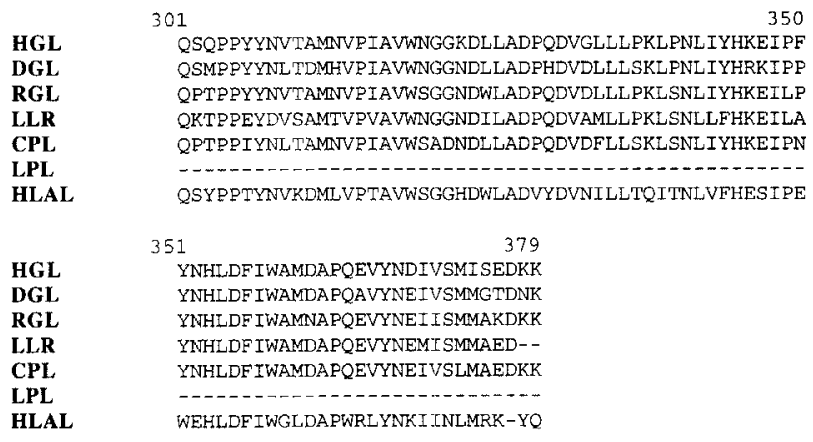

Fig. 3. Amino-acid sequences of acid lipases. Human gastric lipase (HGL; Bodmer et al. 1987), dog gastric lipase (DGL; Bénicourt et al. 1993), rabbit gastric lipase (RGL; Bénicourt et al. 1993), rat lingual lipase (RLL; Docherty et al. 1985), calf pharyngeal lipase (CPL; Timmermans et al. 1994), lamb pharyngeal lipase (LPL; de Caro et al. 1995) and human lysosomal acid lipase (HLAL; Anderson \& Sando, 1991). 
calf lipase where only two cysteines were found (Cys 227 and Cys 236). Using classical sulphydryl reagents such as 5,5'-dithiobis(2-nitrobenzoic acid) (DTNB) or 4,4'-dithiopyridine (4-PDS) only one sulphydryl group was titrated per mol native or SDS-treated HGL (Gargouri et al. 1988), RGL (Moreau et al. 1988c) and DGL (Carrière et al. 1991). Moreover, a direct correlation was found between the modification of the sulphydryl group and the loss of lipolytic activity (Gargouri et al. 1988). As only one free sulphydryl group was titrated, one can assume that gastric lipases contain a single disulphide bridge.

Incubation of the three gastric lipases with a new amphiphilic reagent synthesized in our laboratory, dodecyldithio-5-(2-nitrobenzoic acid) $\left(\mathrm{C}_{12}-\mathrm{TNB}\right)$, used in a molar excess of 30 , induced a total loss of lipolytic activity. In the presence of emulsified tributyrin, gastric lipases were completely inactivated when $\mathrm{C}_{12}$-TNB was injected after addition of the enzyme. In contrast, the two classical sulphydryl reagents must be pre-incubated with lipases to inhibit them (Gargouri et al. 1991). This result is explained by the amphipathic nature of this new compound, which allows it to interact with lipid-water interfaces and to react rapidly with the sulphydryl group of gastric lipase. Thus, it can be concluded that HGL, RGL and DGL possess a sulphydryl group which is essential for the expression of their catalytic activity.

Gastric lipases, like pancreatic lipases, are specifically inhibited by micellar diethyl p-nitrophenyl phosphate (E600; Moreau et al. 1991), which is a well-known serine esterase inhibitor. E600 inhibits the catalytic step and not the binding at the interface. A characteristic amino acid sequence of lipases was identified; this sequence is a decapeptide including the serine of the catalytic triad $\left(\mathrm{S}^{*}\right)$.

$$
\text { [LIV]-X-[LIVFY]-[LIVST]-G-[HYWV]-S*-X-G-[GSTAC] }
$$

For the five preduodenal lipases this decapeptide is located in position 147-156. The conserved serine, Ser 153, within this decapeptide could correspond to Ser 152 in human pancreatic lipase, which is the active site serine.

The gene structures of HGL and HLAL are very similar, with Ser 153, Asp 324 and His 353 as members of a putative catalytic triad, as found in other lipases. The same authors have proposed that residues Cys 227 and Cys 236 form a disulphide bridge, identifying an 8 amino acid amphipathic $\alpha$-helical lid which is probably displaced upon interfacial adsorption. The lids of various acid lipases are interchangeable, indicating that the lid does not determine the substrate specificity (Lohse et al. 1995).

In contrast to pancreatic lipase, all these lipases were characterized by their high stability and high levels of enzymic activity under acidic $\mathrm{pH}$ conditions ( $\mathrm{pH} 1$ and 2 ). In vitro, these lipases present an optimum enzymic activity at $\mathrm{pH}$ values between 4 and 6 (Gargouri et al. 1989; Carrière et al. 1994).

\section{EPITOPE MAPPING OF HUMAN GASTRIC LIPASE USING MONOCLONAL ANTIBODIES}

The micro-crystals obtained from gastric lipases (Moreau et al. 1992) turned out to be unsuitable for X-ray diffraction studies. In the absence of three-dimensional structural data on these lipases, it was decided to develop at our laboratory an immunological approach using monoclonal (mAb) and polyclonal (pAb) antibodies, with a view to performing epitope mapping on the functional sites of human gastric lipase.

A series of $\mathrm{mAb}$ was produced from hybridomas which were obtained by hybridizing 

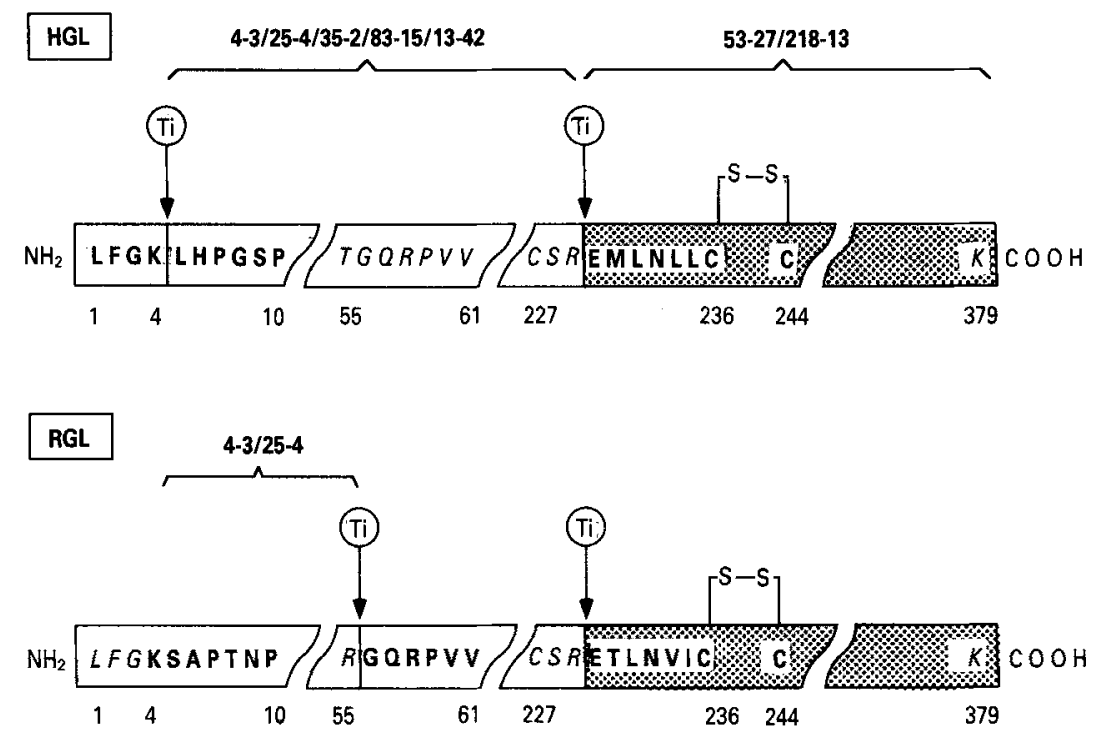

Fig. 4. Schematic representation of the primary sequence of human gastric lipase (HGL; adapted from Bodmer et al. 1987), and rabbit gastric lipase (RGL; adapted from Bénicourt et al. 1993) showing the tryptic cleavage sites (Ti) and the $\mathrm{N}$-terminal domain $(\square)$ as well as the $\mathrm{C}$-terminal domain ( Amino acid-sequenced peptides, determined by Edman degradation, are shown in bold and those deduced from the cDNA sequences are shown in italics. $\sim$, The antigenic determinants of the corresponding monoclonal antibodies; for details, see p. 11 .

murine myeloma cells and mouse spleen cells immunized with pure HGL (Aoubala et al. 1993a). Epitope mapping was carried out on HGL as follows:

(1) by immunoactivating the lipase activity of HGL in order to define the classes of mAb on the basis of their inhibitory effects (Aoubala et al. 1993a);

(2) by performing co-titration assays using the ELISA technique to investigate the simultaneous interactions between two mAb and the enzyme (Aoubala et al. 1993a);

(3) by carrying out trypsinolysis assays in order to localize the preferential peptidic cleavage sites present in HGL and RGL (Aoubala et al. 1994). The peptides obtained were analysed using a microsequencing method and by performing immunotransfer with the various anti-HGL mAb.

On the basis of these data, we drew up a linear map of two antigen regions, showing which epitopes are recognized by the various $\mathrm{mAb}$ and the relationships between the functional domains of the HGL (Aoubala et al. 1994; Fig. 4).

One group of five $\mathrm{mAb}$ was found to recognize epitopes localized at the level of the $\mathrm{N}$-terminal domain. These $\mathrm{mAb}$ inhibit the lipolytic activity of the enzyme. We believe the epitopes recognized by these mAb, to be located near the enzyme's functional sites. The second group (consisting of $2 \mathrm{mAb}$ ) recognized an epitope which was localized at the level of the $\mathrm{C}$-terminal region. These $\mathrm{mAb}$ had no inhibitory effects on the lipolytic activity of the enzyme. This result suggests that the C-terminal domain may not be directly involved in the lipid hydrolysis catalysed by HGL. The data obtained in the trypsinolysis studies made it possible to identify one free sulphydryl group in position 227 and a disulphide bridge in position Cys 236-Cys 244 .

We then attempted to determine the nature of the inhibitory effect exerted by the 
$\mathrm{mAb}$, using the monomolecular film technique to establish which stage in the catalysis (i.e. the interaction with the lipid interface or the catalysis) was involved. As the result of our study on the effects of mAb on the interaction between HGL and a monomolecular lipid film, we determined the tensioactivity of immunoglobulins $G$. It turned out that these immunoglobulins are much less tensioactive than many other proteins, such as lipases, serumalbumin and ovalbumin (Ivanova et al. 1993). Thanks to this unique behaviour of immunoglobulins $\mathrm{G}$, we were able to interpret without any ambiguity the effects of $\mathrm{mAb}$ on the adsorption of human gastric lipase.

A sensitive immunoenzymic test was subsequently developed for measuring the amounts of HGL, and the complexes with $\mathrm{mAb}$, adsorbed at lipid-water interfaces. With this ELISA test it was possible to measure the excess HGL present at the interface, and to calculate for the first time the specific activity on dicaprin monomolecular films (Aoubala et al. 1995). At a surface pressure of $35 \mathrm{mN} / \mathrm{m}$, the specific activity was comparable with that previously obtained with a tributyrin emulsion using the potentiometric $\mathrm{pH}$-stat technique (i.e. $1200 \mathrm{U} / \mathrm{mg}$ ). Of the anti-HGL mAb tested (4-3, 35-2, 83-15 and 218-13 mAb) all except mAb 218-13 significantly decreased the amount of HGL adsorbed at lipid interfaces. The specific activities of HGL and the complexes with $\mathrm{mAb}$ were measured on a dicaprin monomolecular film, and the results showed that the $\mathrm{mAb}$ affected HGL in two ways. When forming complexes with HGL, mAb 4-3, 25-4 and 35-2 decrease both the adsorption and the catalytic activity of HGL, which suggests that the enzyme's two functional sites (the site of the interaction with the lipid and the catalytic site) may be located near each other in the molecule's three-dimensional structure. Although mAb 83-15 may have no effect at all on the specific activity of HGL, it inhibits its adsorption at the interface. The latter antibody, therefore, seems to interact with a region of HGL which is involved in the enzyme's interactions with the lipid interface (Aoubala et al. 1995).

MAb 35-2 and an anti-HGL pAb have both been used to develop a 'sandwich ELISA' immunoenzymic test (Aoubala et al. 1993b). The detection level obtained with this new method is of the order of $1 \mathrm{ng} / \mathrm{ml}$. Thanks to its high specificity, this test has made it possible to distinguish for the first time between HGL and the HPL present in the duodenal contents during the digestion of a test meal by human subjects (Carrière et al. 1993). It should be possible also to further apply this method to establishing relationships existing between the levels of enzyme secretion and diseases involving gastric insufficiency (e.g. gastritis, stomach cancer, gastric ulcers).

\section{FUNCTIONAL ORGANIZATION OF PANCREATIC LIPASE IN SEVERAL STRUCTURAL DOMAINS}

The resolution of the three-dimensional structure of HPL by Winkler et al. (1990) confirmed the existence of two distinct domains in pancreatic lipase, a larger $\mathrm{N}$-terminal domain comprising residues 1-336, and a smaller C-terminal domain made up of residues 337-449. This scheme had previously been suggested by Bousset-Risso et al. (1985). The high degree of amino acid sequence homology observed within the lipase gene family supports the view that this particular architecture is also common to lipoprotein lipase (EC 3.1.1.34) and to hepatic lipase (Kirchgessner et al. 1989; Persson et al. 1989; Derewenda \& Cambillau, 1991; Hide et al. 1992; van Tilbeurgh et al. 1994).

The large $\mathrm{N}$-terminal domain is a typical $\mathrm{a} / \mathrm{b}$ structure dominated by a central parallel 
b-sheet (Ollis et al. 1992). It contains the active site with a catalytic triad formed by Ser 152, Asp 176, His 263, all of which are conserved in lipoprotein lipase and hepatic lipase. This catalytic triad is chemically analogous to that originally described in serine proteases such as chymotrypsin (EC 3.4.21.1; Blow, 1971) but is structurally distinct. The $\beta$-strand $/ \varepsilon$ Ser/ $\alpha$-helix structural motif including the Gly-X-Ser-X-Gly consensus sequence has been detected only in lipases and esterases (Derewenda \& Cambillau, 1991; Derewenda \& Sharp, 1993). The structure of HPL clearly demonstrated that Ser 152 is the nucleophilic residue essential for catalysis, in agreement with the chemical modification of Ser 152 in porcine pancreatic lipase (Guidoni et al. 1981), but in contradiction to results suggesting a function of Ser 152 in interfacial recognition (Chapus \& Sérémiva, 1976).

In the structure resolved by Winkler et al. (1990), the active site is covered by a surface loop between the disulphide bridge Cys 237 and 261. This surface loop includes a short one-turn $\alpha$-helix with a tryptophan residue (Trp 252) completely buried and sitting directly on top of the active site Ser 152. Under this closed conformation, the 'lid' prevents the substrate from having access to the active site. Spectroscopic studies of tryptophan fluorescence have shown that large spectral changes are induced by acylation of pancreatic lipase with the inhibitor tetrahydrolipstatin in the presence of bile salt micelles (Lüthi-Peng \& Winkler, 1992). By crystallizing the pancreatic lipaseprocolipase complex in the presence of mixed lipid micelles, it was shown that the 'lid' was shifted to one side, exposing both the active site and a larger hydrophobic surface (van Tilbeurgh et al. 1993). This motion is induced when binding to the lipid occurs and is probably the structural basis for interfacial activation of pancreatic lipase, as illustrated in Fig. 5.

The $\beta$-sandwich $C$-terminal domain of pancreatic lipase is necessary for colipase binding to occur, as shown in the three-dimensional structure of the HPL-porcine procolipase complex (van Tilbeurgh et al. 1992). Procolipase is a 'three-finger' protein which is topologically comparable with snake toxins, even though these proteins do not share any sequence homology. Colipase lacks any well-defined secondary structure elements. This small protein seems to be stabilized mainly by an extended network of five disulphide bridges that runs throughout the flat-shaped molecule, reticulating its four finger-like loops. The colipase surface can be divided into a rather hydrophilic part, interacting with lipase, and a more hydrophobic part, formed by the tips of the fingers which are very mobile and constitute the lipid interaction surface. The interaction between colipase and the $\mathrm{C}$-terminal domain of lipase is stabilized by eight $\mathrm{H}$ bonds and about 80 van der Waals' contacts. On the opening of the 'lid', three more $\mathrm{H}$ bonds and about 28 van der Waals' contacts are added, explaining the higher apparent affinity in the presence of a lipid-water interface. In the absence of an interface, no conformational change in the lipase molecule is induced by the binding of procolipase. The structure of the open form of the HPL-procolipase complex in the presence of mixed lipid micelles revealed, however, that the 'lid' binds to the procolipase $\mathrm{N}$-terminal domain when the complex is activated at an interface (van Tilbeurgh et al. 1993). The open structure of the lipase-procolipase complex illustrates how colipase might anchor the lipase at the interface in the presence of bile salts; colipase binds to the non-catalytic $\beta$-sheet of the C-terminal domain of HPL and exposes the hydrophobic tips of its fingers at the opposite site of its lipase-binding domain. This hydrophobic surface, in addition to the hydrophobic back side of the 'lid', helps to bring the catalytic N-terminal domain of HPL into close contact with the lipid-water interface. 


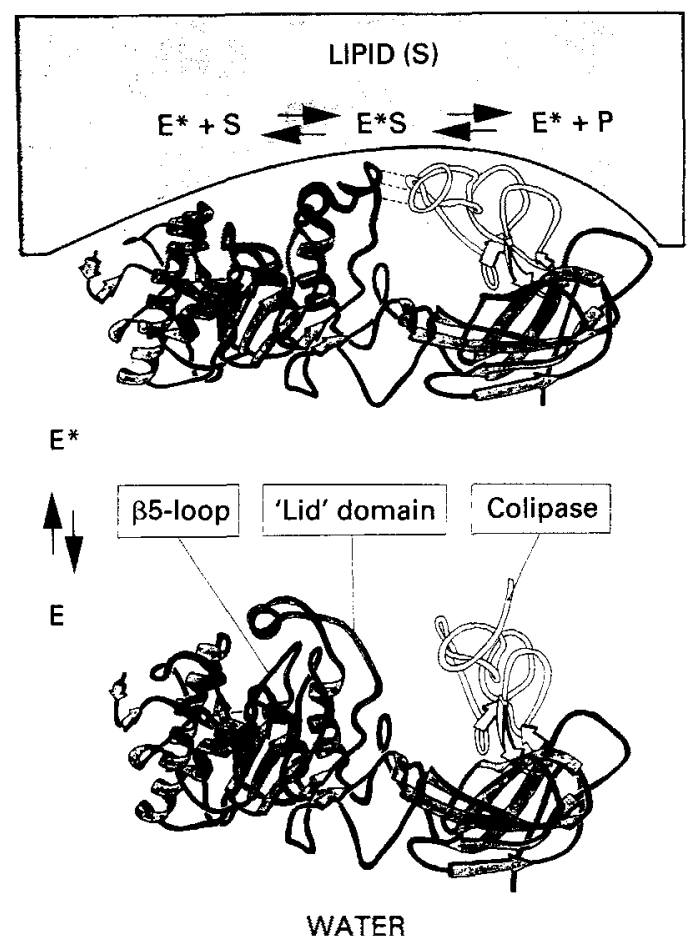

Fig. 5. Structure of HPL-procolipase complex in the closed conformation (E), and structure of HPLprocolipase complex in the open conformation $\left(E^{*}\right)$. Also shown are the conformational changes in the 'lid', the $\beta 5$-loop, and the colipase during interfacial activation. $\mathrm{S}$, substrates; $\mathrm{P}$, products.

\section{DETAILS OF THE INTERFACIAL ACTIVATION OF HUMAN PANCREATIC LIPASE}

In solution (absence of interface), the classical HPL is in a closed conformation ( $\mathrm{E}$ form in Fig. 5; Winkler et al. 1990; van Tilbeurgh et al. 1992). The active site is completely inaccessible to solvent due to the conformation of the 'lid' domain, which also interacts with another surface loop, the $\beta 5$-loop (residues 76 to 85 ) according to the Winkler et al. (1990) nomenclature. A residue in the 'lid' region, Trp 252, is structurally located directly on top of the active Ser 152, with the indole ring packed against Phe 77, a residue which belongs to the $\beta 5$-loop. In the presence of an interface, the 'lid' domain as well as the $\beta 5$-loop undergo large conformational changes, creating a hydrophobic active-site groove and adjusting the hydrolytic machinery ( $\mathrm{E}^{*} \mathrm{~S}$ form in Fig. 5; van Tilbeurgh et al. 1993).

The opening of the active site is caused by a structurally complicated re-organization of the complete 'lid' domain between Cys 237 and Cys 261. As mentioned previously, this surface loop contains a short $\alpha$-helix (residues 248 to 255 ) covering the active site in the closed conformation of HPL. In the presence of lipids, this helix partially unwinds and two new helices are formed (residues 241 to 246 , and residues 251 to 259). The conformational change in the 'lid' results in a maximal main-chain movement of $2.9 \mathrm{~nm}$ for Ile 248. The substrate now has access to the active site. The Trp 252, which filled the 
active-site pocket in the closed conformation, is now conveyed to the surface of the molecule and is involved in a new interaction with the core of the protein.

Another consequence of the 'lid' re-organization is the conformational change of the $\beta 5$-loop. In the closed conformation of the HPL-procolipase complex, this loop makes van der Waals' contact exclusively with the 'lid'. In the open conformation, these interactions are lost and the 35 -loop is lifted back onto the core of the protein. This movement creates an electrophilic region close to the active site Ser 152 . This is probably the so-called oxyanion hole which stabilizes the transition-state intermediate formed during catalysis. The main-chain $\mathbf{N}$ of Phe 77 , from the $\beta 5$-loop, moves to an ideal position to stabilize the negative charge developed during ester hydrolysis. The main-chain $\mathrm{N}$ of Leu 153 is also involved in the formation of the oxyanion hole.

In the open conformation of the HPL-procolipase complex, procolipase also binds to the 'lid' domain. This interaction is mediated by the three direct $\mathrm{H}$ bonds between residues of the 'lid' (Val 246, Ser 243, Asn 24) and residues of the procolipase N-terminal domain (Arg 38, Leu 16, Glu 15) respectively. The latter domain undergoes a considerable conformational change from the closed to the open conformation of the complex.

As a result of all these conformational changes, the open 'lid' and the extremities of the procolipase fingers form an impressive continuous hydrophobic plateau, extending over more than $5 \mathrm{~nm}$. This surface might be able to interact strongly with a lipid-water interface, and this might explain the effects of colipase in the presence of bile salts.

A racemic mixture of the $C_{11}$ alkyl phosphonate inhibitor was recently used in the crystallization of the pancreatic lipase-colipase complex, and there is evidence that both enantiomers are bound at the active site (Egloff et al. 1995). The $\mathrm{C}_{11}$ alkyl chain of the first enantiomer fits into a hydrophobic groove and this is thought to mimic the interaction of the leaving fatty acid of a TAG substrate. The alkyl chain of the second enantiomer also has an elongated conformation and interacts with hydrophobic patches on the surface of the open amphipathic 'lid'. This binding mode may be indicative of an interaction with a second alkyl chain of a TAG substrate (Egloff et al. 1995). The most challenging problem results, however, from the fact that lipases differ dramatically in their specific activities and stereopreferences, and generalizing the previously described results obtained with just one or two enzymes is simply not possible.

This work was supported by the BRIDGE-T-lipase Programme of the European Communities under Contract BIOT-CT910274 (DTEE) and by BIOTECH G-Program BIO 2-CT94-3041.

\section{REFERENCES}

Anderson, R. A. \& Sando, G. N. (1991). Cloning and expression of cDNA encoding human lysosomal acid lipase/cholesteryl ester hydrolase. Similarities to gastric and lingual lipases. Journal of Biological Chemistry 266, 22479-22484.

Aoubala, M., Bonicel, J. Bénicourt, C., Verger, R. \& de Caro, A. (1994). Tryptic cleavage of gastric lipases: Location of the single disulfide bridge. Biochimica et Biophysica Acta 1213, 319-324.

Aoubala, M., Daniel, C., de Caro, A., Ivanova, M. G., Hirn, M., Sarda, L. \& Verger, R. (1993a). Epitope mapping and immunoinactivation of human gastric lipase using five monoclonal antibodies. European Journal of Biochemistry 211, 99-104.

Aoubala, M., Douchet, I., Laugier, R., Hirn, M., Verger, R. \& de Caro, A. (1993b). Purification of human gastric lipase by immunoaffinity and quantification of this enzyme in the duodenal contents using a new ELISA procedure. Biochimica et Biophysica Acta 1169, 183-188. 
Aoubala, M., Ivanova, M., Douchet, I., de Caro, A. \& Verger, R. (1995). Interfacial binding of Human Gastric Lipase to lipid monolayers, measured with an ELISA. Biochemistry 34, 10786-10793.

Bénicourt, C., Blanchard, C., Carrière, F., Verger, R. \& Junien, J.-L. (1993). Potential use of a recombinant dog gastric lipase as an enzymatic supplement to pancreatic extracts in cystic fibrosis. In Clinical Ecology of Cystic Fibrosis, pp. 291-295 [H. Escobar, C. F. Baquero and L. Suárez, editors]. Amsterdam: Elsevier Science Publishers B.V.

Bernbäck, S., Bläckberg, L. \& Hernell, O. (1989). Fatty acids generated by gastric lipase promote human milk triacylglycerol digestion by pancreatic colipase-dependent lipase. Biochimica et Biophysica Acta 1001, 286-291.

Bernbäck, S., Hernell, O. \& Bläckberg, L. (1985). Purification and molecular characterization of bovine pregastric lipase. European Journal of Biochemistry 148, 233.

Blow, D. M. (1971). The structure of chymotrypsin. In The Enzymes, vol. 3, pp. 185-212 [P. D. Boyer, editor]. New York and London: Academic Press.

Bodmer, M. W., Angal, S., Yarranton, G. T., Harris, T. J. R., Lyons, A., King, D. J., Piéroni, G., Rivière, C., Verger, R. \& Lowe, P. A. (1987). Molecular cloning of a human gastric lipase and expression of the enzyme in yeast. Biochimica et Biophysica Acta 909, 237-244.

Borgström, B. (1980). The importance of phospholipids, pancreatic phospholipase $A_{2}$ and fatty acid for the digestion of dietary fat. Gastroenterology 78, 954-962.

Bousset-Risso, M., Bonicel, J. \& Rovery, M. (1985). Limited proteolysis of porcine pancreatic lipase. FEBS Letters 182, 323-326.

Carrière, F., Barrowman, J. A., Verger, R. \& Laugier, R. (1993). Secretion and contribution to lipolysis of gastric and pancreatic lipases during a test meal in humans. Gastroenterology 105, 876-888.

Carrière, F., Gargouri, Y., Moreau, H., Ransac, S., Rogalska, E. \& Verger, R. (1994). Gastric lipases: Cellular, biochemical and kinetic aspects. In Lipases: Their Structure, Biochemistry and Application, pp. 181-205 [P. Wooley and S. B. Petersen, editors]. Cambridge: Cambridge University Press.

Carrière, F., Moreau, H., Raphel, V., Laugier, R., Bénicourt, C., Junien, J.-L. \& Verger, R. (1991). Purification and biochemical characterization of dog gastric lipase. European Journal of Biochemistry 202, 75-83.

Chapus, C. \& Sérémiva, M. (1976). Mechanism of pancreatic lipase action. 2. Catalytic properties of modified lipases. Biochemistry 15, 4988-4991.

de Caro, J., Ferrato, F., Verger, R. \& de Caro, A. (1995). Purification and molecular characterization of lamb pregastric lipase. Biochimica et Biophysica Acta 1252, 321-329.

de Nigris, S. J., Hamosh, M., Kasbedar, D. K., Lee, T. C. \& Hamosh, P. (1988). Lingual and gastric lipases: Species differences in the origin of prepancreatic digestive lipases and in the localization of gastric lipase. Biochimica et Biophysica Acta 958, 38-45.

Derewenda, Z. S. \& Cambillau, C. (1991). Effects of gene mutations in lipoprotein and hepatic lipases as interpreted by a molecular model of the pancreatic triglyceride lipase. Journal of Biological Chemistry 266, 23112-23119.

Derewenda, Z. S. \& Sharp, A. M. (1993). News from the interface: the molecular structures of triacylglyceride lipases. Trends in Biochemical Sciences 18, 20-25.

Docherty, A. J. P., Bodmer, M. W., Angal, S., Verger, R., Rivière, C., Lowe, P. A., Lyons, A., Emtage, J. S. \& Harris, T. J. R. (1985). Molecular cloning and nucleotide sequence of rat lingual lipase cDNA. Nucleic Acid Research 13, 1891-1903.

Egloff, M.-P., Marguet, F., Buono, G., Verger, R., Cambillau, C. \& van Tilbeurgh, H. (1995). The $2.46 \AA$ resolution structure of the pancreatic lipase-colipase complex inhibited by a $\mathrm{C} 11$ alkyl phosphonate. Biochemistry 34, 2751-2762.

Field, R. \& Scow, R. O. (1983). Purification and characterization of rat lingual lipase. Journal of Biological Chemistry 258, 14563-14569.

Gargouri, Y., Chahinian, H., Moreau, H., Ransac, S. \& Verger, R. (1991). Inactivation of pancreatic and gastric lipases by THL and $\mathrm{C}_{12: 0^{-}}$TNB: a kinetic study with emulsified tributyrin. Biochimica et Biophysica Acta 1085, 322-328.

Gargouri, Y., Moreau, H., Piéroni, G. \& Verger, R. (1988). Human gastric lipase: A sulfhydryl enzyme. Journal of Biological Chemistry 263, 2159-2162.

Gargouri, Y., Moreau, H. \& Verger, R. (1989). Gastric lipases: Biochemical and physiological studies. Biochimica et Biophysica Acta 1006, 255-271.

Gargouri, Y., Piéroni, G., Rivière, C., Lowe, P. A., Saunière, J.-F., Sarda, L. \& Verger, R. (1986). Importance of human gastric lipase for intestinal lipolysis: An in vitro study. Biochimica et Biophysica Acta $879,419-423$. 
Guidoni, A., Benkouka, F., de Caro, J. \& Rovery, M. (1981). Characterization of the serine reacting with diethyl $p$-nitrophenylphosphate in porcine pancreatic lipase. Biochimica et Biophysica Acta 660, 148-150.

Hamosh, M. (1984). Lingual lipase. In Lipases, pp. 49-81 [B. Borgström and H. L. Brockman, editors]. Amsterdam: Elsevier.

Hamosh, M., Ganot, D. \& Hamosh, P. (1979). Rat lingual lipase: Characteristics of enzyme activity. Journal of Biological Chemistry 254, 12121-12125.

Hide, W. A., Chan, L. \& Li, W. H. (1992). Structure and evolution of the lipase superfamily. Journal of Lipid Research 33, 167-178.

Hull, M. \& Keaton, R. W. (1917). The existence of a gastric lipase. Journal of Biological Chemistry 32, $127-140$.

Ivanova, M. G., Aoubala, M., de Caro, A., Daniel, C., Hirn, J. \& Verger, R. (1993). A study on human gastric lipase and complexes with monoclonal antibodies using the monomolecular film technique. Colloids and Surfaces B1, 17-22.

Kirchgessner, T. G., Chuat, J. C., Heinzmann, C., Etienne, J., Guilhot, S., Svenson, K., Ameis, D., Pilon, C., d'Auriol, L., Andalibi, A., Schotz, M. C., Galibert, F. \& Lusis, A. J. (1989). Organization of the human lipoprotein lipase gene and evolution of the lipase gene family. Proceedings of the National Academy of Sciences, USA 86, 9647-9651.

Lohse, P., Lohse, P. \& Seidel, D. (1995). Human lysosomal acid lipase: Functional analysis of the putative lid structure covering the active site. Proceedings of the American Heart Association. 68th Scientific session. Anaheim, California: Mosby.

Lüthi-Peng, Q. \& Winkler, F. K. (1992). Large spectral changes accompany the conformational transition of human pancreatic lipase induced by acylation with the inhibitor tetrahydrolipstatin. European Journal of Biochemistry 205, 383-390.

Moreau, H., Abergel, C., Carrière, F., Ferrato, F., Fontecilla-Camps, J. C., Cambillau, C. \& Verger, R. (1992). Isoform purification of gastric lipases. Towards crystallization. Journal of Molecular Biology 225, $147-153$.

Moreau, H., Gargouri, Y., Lecat, D., Junien, J.-L. \& Verger, R. (1988a). Screening of preduodenal lipases in several mammals. Biochimica et Biophysica Acta 959, 247-252.

Moreau, H., Gargouri, Y., Lecat, D., Junien, J.-L. \& Verger, R. (1988b). Purification, characterization and kinetic properties of the rabbit gastric lipase. Biochimica et Biophysica Acta 960, 286-293.

Moreau, H., Gargouri, Y., Piéroni, G. \& Verger, R. (1988c). Importance of sulfhydryl group for rabbit gastric lipase activity. FEBS Letters 236, 383-387.

Moreau, H., Moulin, A., Gargouri, Y., Noël, J.-P. \& Verger, R. (1991). Inactivation of gastric and pancreatic lipases by diethyl p-nitrophenyl phosphate. Biochemistry 30, 1037-1041.

Mossi, S., Aoubala, M. de Caro, A., Verger, R. \& Laugier, R. (1994). Gastric lipase (GL) becomes essential for the lipid digestion during severe pancreatic exocrine insufficiency (PEI). Digestion 55, 328.

Ollis, D. L., Cheah, E., Cygler, M., Dijkstra, B., Frolow, F., Franken, S. M., Harel, M., Remington, S. J., Silman, I., Schrag, J., Sussman, J. L., Verschueren, K. H. G. \& Goldman, A. (1992). The $\alpha / \beta$ hydrolase fold. Protein Engineering 5, 197-211.

Persson, B., Bentsson-Olivecrona, G., Enerbäck, S., Olivecrona, T. \& Jörnvall, H. (1989). Structural features of lipoprotein lipase. Lipase family relationships, binding interactions, non-equivalence of lipase cofactors, vitellogenin similarities and functional subdivision of lipoprotein lipase. European Journal of Biochemistry $179,39-45$.

Rizek, R. L., Friend, B. \& Page, L. (1974). Fat in today's food supply. Level of use and source. Journal of the American Oil Chemists' Society 52, 244-250.

Roberts, I. M., Montgomery, R. K. \& Carey, M. C. (1984). Lingual lipase: Partial purification, hydrolytic properties and comparison with pancreatic lipase. American Journal of Physiology 247G, 385-393.

Ross, C. A. C. \& Sammons, H. C. (1955). Non-pancreatic lipase in children with pancreatic fibrosis. Archives of Disease in Childhood 30, 428-431.

Roulet, M., Weber, A. M., Paradis, Y., Roy, C. C., Chartraud, L., Lasalle, R. \& Morin, C. L. (1980). Gastric emptying and lingual lipase activity in cystic fibrosis. Pediatric Research 14, 1360-1362.

Timmermans, M. Y. J., Teuchy, H. \& Kupers, L. P. M. (1994). The cDNA sequence encoding bovine pregastric esterase. Gene 147, 259-262.

Tiruppathi, C. \& Balasubramanian, K. A. (1982). Purification and properties of an acid lipase from human gastric juice. Biochimica et Biophysica Acta 712, 692-697.

van Tilbeurgh, H., Egloff, M.-P., Martinez, C., Rugani, N., Verger, R. \& Cambillau, C. (1993). Interfacial activation of the lipase-procolipase complex by mixed micelles revealed by X-Ray crystallography. Nature 362,814820 
van Tilbeurgh, H., Roussel, A., Lalouel, J. M. \& Cambillau, C. (1994). Lipoprotein lipase. Molecular model based on the pancreatic lipase X-Ray structure: consequences for heparin binding and catalysis. Journal of Biological Chemistry 269, 4626-4633.

van Tilbeurgh, H., Sarda, L., Verger, R. \& Cambillau, C. (1992). Structure of the pancreatic lipaseprocolipase complex. Nature 359, 159-162.

Volhard, F. (1901). Uber das Fettspaltende fermentdes magens. (On the fat-splitting enzymes of the stomach.) Zeitschrift für Klinische Medizin 42, 414-429.

Winkler, F. K., d'Arcy, A. \& Hunziker, W. (1990). Structure of human pancreatic lipase. Nature 343, 771-774. 